\title{
DETERMINAN KINERJA KARYAWAN BANK SULSELBAR SYARIAH
}

\author{
Nuraeni Gani \\ Universitas Islam Negeri Alauddin Makassar \\ hjnuraeni.gani@gmail.com
}

\section{Keywords: \\ Incentives, Organizational \\ Commitment, Interpersonal \\ Communication and \\ Employee Performance.}

\section{Kata Kunci:}

Insentif, Komitmen

Organisasi, Komunikasi

Interpersonal dan

Kinerja Karyawan.

\section{ABSTRACT}

This study aims to determine and analyze the influence, organizational commitment, and interpersonal communication on employee performance in Bank Sulselbar Syariah. The sample uses the Sample method, ie. All samples were 47 respondents at Bank Sulselbar Syariah. Methods of data retrieval used are direct interviews to the parties involved with the problem being done and provide questionnaires to employees in accordance with the research undertaken. Data analysis was done by using multiple linear regression analysis, T-test, F test and Determination Coefficient Test (R2). The result of the research shows that (1) policy has positive and significant effect to employee performance in Bank Sulselbar Syariah; (2) organizational commitment has a positive and significant impact on employee performance in Bank Sulselbar Syariah; (1) interpersonal communication has a positive and significant impact on employee performance in Bank Sulselbar Syariah; (4) tendency, organizational commitment and interpersonal communication simultaneously and significantly to employee performance in Bank Sulselbar Syariah.

\begin{tabular}{l}
\hline ABSTRAK \\
\hline Penelitian ini bertujuan untuk mengetahui dan menganalisis \\
pengaruh insentif, komitmen organisasi dan komunikasi \\
interpersonal terhadap kinerja karyawan di Bank Sulselbar Syariah. \\
Sampel menggunakan metode Sampel jenuh, yaitu semua anggota \\
populasi digunakan sebagai sampel. Semua sampel berjumlah 47 \\
responden pada Bank Sulselbar Syariah. Metode pengumpulan data \\
yang digunakan adalah Wawancara langsung kepada pihak-pihak \\
yang terlibat dengan masalah yang sedang dibahas serta \\
memberikan kuesioner kepada karyawan yang sesuai dengan \\
penelitian yang dilakukan. Analisis data dilakukan dengan \\
menggunakan analisa regresi linear berganda, Uji T-test, Uji F serta \\
Uji Koefisien Determinasi (R2). Hasil analisis menunjukan bahwa \\
(1) insentif berpengaruh berpengaruh positif dan signifikan \\
terhadap kinerja karyawan di Bank Sulselbar Syariah; (2) komitmen \\
organisasi berpengaruh berpengaruh positif dan signifikan terhadap \\
kinerja karyawan di Bank Sulselbar Syariah; (1) komunikasi \\
interpersonal berpengaruh berpengaruh positif dan signifikan \\
terhadap kinerja karyawan di Bank Sulselbar Syariah; (4) insentif, \\
komitmen organisasi dan komunikasi interpersonal secara simultan \\
berpengaruh positif dan signifikan terhadap kinerja karyawan di \\
Bank Sulselbar Syariah.
\end{tabular}

\section{PENDAHULUAN}

Perusahaan sebagai sebuah organisasi yang menghasilkan produk atau jasa sangat membutuhkan sumber daya bagi kegiatan operasinya. Sumber daya yang dibutuhkan itu terdiri dari sumber daya fisik (man, money, method, market, machine,material) dan sumber daya konseptual 
(informasi / data).Manusia sebagai salah satu sumberdaya insani berperan dalam menentukan semua kegiatan yang ada di perusahaan yang tercermin melalui kinerja karyawan. Kinerja merupakan sesuatu yang sangat kompleks dan senantiasa perlu ditingkatkanbaik dari sisi individu, kelompok maupun organisasi.Suatu organisasi atau instansicenderung memilih karyawan yang merniliki pengalaman kerja yang banyak, atau dengankata lain yang memiliki masa kerja yang cukup pada bidang kerja yang sama atau sejenisdengan apa yang akan ditugaskan nantinya

Menurut Simamora (2004), deskripsi dari kinerja menyangkut tiga komponen penting, yaitu tujuan yang akan memberikan arah dan mempengaruhi bagaimana seharusnya perilaku kerja yang diharapkan organisasi terhadap setiap personel. Kedua adalah ukuran, dibutuhkan untuk mengetahui apakah seorang personel telah mencapai kinerja yang diharapkan, untuk itu kuantitatif dan kualitatif standar kinerja untuk setiap tugas dan jabatan personal memegang peranan penting. Ketiga, penilaian kinerja reguler, yang dikaitkan dengan proses pencapaian tujuan kinerja setiap personel. Tindakan ini akan membuat personel untuk senantiasa berorientasi terhadap tujuan dan berperilaku kerja sesuai dan searah dengan tujuan yang hendak dicapai. Kinerja memiliki arti suatu hasil kerja yang dapat dicapai oleh seseorang atau sekelompok orang dalam suatu organisasi sesuai dengan wewenang dan tanggung jawab masing-masing. dalam rangka mencapai tujuan organisasi secara legal, tidak melanggar hukum dan sesuai dengan moral maupun etika kinerja pada dasarnya adalah apa yang dilakukan atau tidak dilakukan karyawan sehingga mempengaruhi seberapa banyak mereka memberi kontribusi kepada instansi atau organisasi termasuk pelayanan kualitas yang disajikan, Menurut Mathis dan Jackson (2006).

Insentif memiliki keterkaitan dengan kinerja karyawan. Menurut Hasibuan (2002), mengemukakan bahwa Insentif adalah tambahan balas jasa yang diberikan kepada karyawan tertentu yang prestasinya di atas prestasi standar. Insentif ini merupakan alat yang dipergunakan pendukung prinsip adil dalam pemberian kompensasi. Selain itu menurut Mangkunegara (2006), mengemukakan bahwa Insentif adalah suatu bentuk motivasi yang dinyatakan dalam bentuk uang atas dasar kinerja yang tinggi dan juga merupakan rasa pengakuan dari pihak organisasi terhadap kinerja karyawan dan kontribusi terhadap organisasi. Berdasarkan uraian diatas jelaslah bahwa kinerja karyawan dipengaruhi oleh insentif. Konsep tersebut diatas sejalan dengan penelitian yang dilakukan oleh Mazura, Mujiono dan Rosmida, (2012), Temuan hasil penelitian menunjukkan bahwa pengaruh insentif terhadap kinerja karyawan berpengaruh positif dan signifikan.

Selain faktor insentif, faktor komitmen organisasi juga mempengaruhi kinerja karyawan. menurut Luthans (2006), komitmen diartikan secara umum sebagai sikap yang menunjukkan loyalitas karyawan dan merupakan proses berkelanjutan bagaimana seorang karyawan instansi mengekspresikan perhatian mereka kepada kesuksesan dan kebaikan organisasinya. Karyawan dengan komitmen tinggi akan memberikan dampak positif dalam bekerja, yaitu memberikan usaha terbaiknya untuk menyelesaikan tugas dengan cepat dan sesuai apa yang ditargetkan. Pendapat lain dikemukakan oleh Handoko (2008), komitmen karyawan adalah tingkatan dimana seorang pekerja mengidentifikasikan diri dengan organisasi dan tujuan-tujuannya dan berkeinginan untuk memelihara keanggotaannya dalam organisasi. Komitmen karyawan didorong dengan kondisi lingkungan kerja yang adil untuk karyawan, semakin tinggi karyawan dihargai, semakin tinggi juga komitmen karyawan pada organisasi tersebut.. Konsep tersebut diatas sejalan dengan penelitian yang dilakukan oleh Arizona, D Dika dkk (2013), Temuan hasil penelitian menunjukkan bahwa komitmen organisasional berpengaruh terhadap kinerja karyawan.

Selain faktor-faktor insentif dan komitmen organisasi yang mempengaruhi kinerja karyawan pada penjelasan diatas, komunikasi interpersonal juga mempengaruhi kinerja karyawan. Menurut Kohler (dalam Devito (2011)) ada dua model komunikasi dalam rangka 
Nuraeni Gani. Determinan Kinerja Karyawan Bank Sulselbar Syariah.

meningkatkan kinerja dan mencapai tujuan perkantoran. Pertama, komunikasi koordinatif, yaitu proses komunikasi yang berfungsi untuk menyatukan bagian-bagian (subsistem) perkantoran. Kedua, komunikasi interaktif, ialah proses pertukaran informasi yang berjalan secara berkesinambungan, pertukaran pendapat dan sikap yang dipakai sebagai dasar penyesuaian di antara sub-sub sistem dalam perkantoran, maupun antara perkantoran dengan mitra kerja. Konsep tersebut diatas sejalan dengan penelitian yang dilakukan oleh Beny Usman (2013), Temuan hasil penelitian menunjukkan bahwa ada pengaruh yang signifikan antara komunikasi interpersonal terhadap kinerja karyawan.

Berdasarkan pengamatan dan wawancara yang dilakukan peneliti, diperoleh bahwa kinerja kerja karyawanBank Sulselbar Syariah saat ini dapat dikatakan cukup rendah. kenyataan empirik menunjukkan bahwa kinerja karyawan tidak maksimal. Hal ini tampak adanya aktivitas yang dilakukan sebagian Karyawan bank yang tidak produktif, masih ada karyawan terlambat masuk kantor dan pulang tidak tepat waktu. Ada kecenderungan karyawan menunda pekerjaan, menunggu perintah atasan. Selain itu permasalahan yang terjadi pada Bank Sulselbar Syariah dalam masalah pemberian insentif yaitu kurangnya perhatian pimpinan terhadap pemberian insentif kepada karyawan, hal ini dapat dilihat dari kurangnya semangat kerja karyawan dalam melaksanakan tugas dan tanggung jawab sehingga kinerja karyawan menurun. Kemudian kondisi yang ada saat ini menunjukkan bahwa komunikasi yang terjadi tidak konstruktif maksudnya cara berkomunikasinya tidak menonjolkan sisi positif dari apa yang disampaikan antara sesama karyawan karena jika ada kesalahan dalam pekerjaan, mereka tidak saling memberi arahan dan petunjuk. Hal ini juga yang menyebabkan kurang baiknya penerimaan feed back (umpan balik), yang dikarenakan adanya perbedaan persepsi tiap karyawan pada pemaknaan informasi yang mereka terima, sehingga sering muncul beberapa kesalahan pada saat pelaksanaan tugas yang seharusnya tidak perlu terjadi.

Dari fenomena yang terjadi di Bank Sulselbar Syariah, maka sepatutnya untuk meningkatkan kinerja karyawan maka faktor-faktor insentif, komitmen organisasi dan komunikasi interpersonal yang harus menjadi perhatian dari pimpinan dan organisasi. Peningkatan kinerja karyawan dalam sebuah instansi sangatlah penting, karena akan berdampak positif bagi instansi dan diharapkan mampu untuk meningkatkan produktivitas dan kinerja organisasi. Salah satu caranya melalui pemberian insentif yang sesuai dengan ketentuan, komitmen organisasi dari karyawan yang tinggi, dan kelancaran komunikasi interpersonal, maka akan memberi dampak terhadap kinerja karyawan.

Tujuan penelitian yang ingin dicapai dalam penelitian ini adalah sebagai berikut: (1) mengetahui dan menganalisis pengaruh insentif terhadap kinerja karyawan di Bank Sulselbar Syariah; (2) mengetahui dan menganalisis pengaruh komitmen organisasiterhadap kinerja karyawan di Bank Sulselbar Syariah; (3) mengetahui dan menganalisis pengaruh komunikasi interpersonalterhadap kinerja karyawan di Bank Sulselbar Syariah (4) mengetahui dan menganalisis pengaruh insentif, komitmen organisasi dan komunikasi interpersonalsecara simultan terhadap kinerja karyawan di Bank Sulselbar Syariah.

\section{LANDASAN TEORI}

\section{a. Konsep Insentif}

Menurut Hariandja (2002). Insentif merupakan salah satu jenis pengahargaan yang dikaitkan dengan prestasi kerja.Semakin tinggi prestasi kerja semakin besar pula insentif yang diterima. Sudah menjadi kebiasaan bahwa setiap perusahaan harus menetapkan target yang tinggi dan bila berhasil maka akan diberikan tambahan pendapatan.

Insentif merupakan bentuk lain dari upah langsung diluar gaji dan upah yang merupakan kompensasi tetap, yang disebut sistem kompensasi berdasarkan kinerja (Pay for 
Performance Plan). Insentif merupakan motivator yang positif bagi para karyawan untuk meningkatkan gairah kerja, kreatifitas dan pengembangan dirinya menuju tenaga yang profesional.

Menurut Jensen dan Meckling dalam Hariandja (2002), insentif digunakan untuk mendorong karyawan dalam memperbaiki kualitas dan kuantitas hasil kerjanya. Pemberian insentif tersebut bermanfaat bagi perusahaan maupun karyawan. Jika insentif yang diterima tidak dikaitkan dengan prestasi kerja, tetapi bersifat pribadi, maka mereka akan merasa adanya ketidakadilan yang dapat mengakibatkan ketidakpuasan yang pada gilirannya dapat mempengaruhi perilaku, misalnya ketidakhadiran dan penurunan prestasi kerja.

Harsono (2003) bahwa insentif adalah setiap sistem kompensasi di mana jumlah yang diberikan tergantung dari hasil yang dicapai yang berarti menawarkan suatu insentif kepada pekerja untuk mencapai hasil yang lebih baik. Heidjrachman dan Husnan (2002) mengatakan bahwa pengupahan insentif dimaksudkan untuk memberikan upah atau gaji yang berbeda. Jadi dua orang karyawan yang mempunyai jabatan yang sama bisa menerima upah yang berbeda dikarenakan prestasi kerja yang berbeda

Sarwoto (2008) Insentif adalah sebagai sarana motivasi dapat diberikan batasan perangsang ataupun pendorong yang diberikan dengan sengaja kepada pekerja agar dalam diri mereka timbul semangat yang lebih besar untuk berprestasi bagi organisasi.

Mangkunegara (2004) Insentif adalah penghargaan atas dasar prestasi kerja yang tinggi yang merupakan rasa pengakuan dari pihak organisasi terhadap prestasi kerja karyawan dan konstitusi pada organisasi. Panggabean (2004) Insentif adalah kompensasi yang mengkaitkan gaji dengan produktivitas. Insentif merupakan penghargaan dalam bentuk uang yang berdasarkan kepada mereka yang dapat bekerja melampaui standar yang telah ditentukan.

Martoyo (2000) Insentif adalah tambahan upah (bonus) karena adanya kelebihan prestasi yang membedakan dengan yang lain, yang dimaksudkan untuk dapat meningkatkan produktivitas karyawan dan mempertahankan karyawan yang berprestasi untuk tetap berada dalam organisasi. Handoko (2002), pengertian insentif adalah: "Perangsang yang ditawarkan kepada para karyawan untuk melaksanakan kerja sesuai atau lebih tinggi dari standar- standar yang telah ditetapkan".

Mangkunegara (2004), insentif adalah: "Suatu penghargaan dalam bentuk uang yang diberikan oleh pihak pemimpin organisasi kepada karyawan agar mereka bekerja dengan motivasi yang tunggi dan berprestasi dalam pencapaian tujuan-tujuan organisasi". Simamora (2004), insentif adalah: "Kompensasi yang mengaitkan bayaran atas dasar untuk dapat meningkatkan produktivitas para karyawan guna mencapai keunggulan yang kompetitif.

\section{b. Komitmen Organisasi}

Komitmen karyawan merupakan salah satu dasar bagi karyawan dalam melakukan pekerjaan. Komitmen yang tinggi memberikan motivasi kuat untuk terus bertahan didalam suatu organisasi dan mencapai tujuan organisasi. Robbins (2007), menyatakan komitmen karyawan merupakan usaha mendefinisikan dan melibatkan diri dalam organisasi dan tidak ada keinginan meninggalkannya. Sedangkan menurut Luthans (2006), komitmen diartikan secara umum sebagai sikap yang menunjukkan loyalitas karyawan dan merupakan proses berkelanjutan bagaimana seorang karyawan instansi mengekspresikan perhatian mereka kepada kesuksesan dan kebaikan organisasinya.

Karyawan dengan komitmen tinggi akan memberikan dampak positif dalam bekerja, yaitu memberikan usaha terbaiknya untuk menyelesaikan tugas dengan cepat dan sesuai apa yang ditargetkan. Pendapat lain dikemukakan oleh Handoko (2008), komitmen karyawan adalah tingkatan dimana seorang pekerja mengidentifikasikan diri dengan organisasi dan tujuan-tujuannya dan berkeinginan untuk memelihara keanggotaannya dalam organisasi. Komitmen karyawan didorong dengan kondisi lingkungan kerja yang adil untuk karyawan, 
Nuraeni Gani. Determinan Kinerja Karyawan Bank Sulselbar Syariah.

semakin tinggi karyawan dihargai, semakin tinggi juga komitmen karyawan pada organisasi tersebut.

Luthans (2006), menjelaskan bahwa komitmen karyawan membawa hasil positif seperti kinerja tinggi, tingkat turnover yang rendah dan tingkat ketidakhadiran yang rendah. Selain itu, komitmen karyawan juga berhubungan dengan hasil lain yang diinginkan, seperti persepsi iklim organisasi, yaitu organisasi yang hangat dan mendukung dan menjadi anggota tim yang baik dan siap membantu.

Komitmen dapat diartikan sebagai identitas diri dan keterlibatan pada organisasi dan keinginan untuk tetap bersama dalam organisasi itu. Menurut Wangsadjaja (2006) mendefinisikan komitmen sebagai kekuatan yang bersifat relatif dari individu dalam identitas dan keterlibatan dirinya ke dalam bagian organisasi. Sikap ini dapat ditandai dengan tiga hal, yaitu kepercayaan yang kuat tentang organisasi yang mewadahi, bersungguh-sungguh demi kepentingan organisasi, dan keinginan kuat mempertahankan keanggotaan di dalam organisasi.

\section{c. Komunikasi Interpersonal}

Komunikasi interpersonal adalah membentuk hubungan dengan orang lain. Cangara (2006) memberikankan pengertian bahwa komunikasi interpersonal atau komunikasi antarpribadi ialah proses komunikasi yang berlangsung antara dua orang atau lebih secara tatap muka. Bungin (2008) menjelaskan bahwa komunikasi interpersonal adalah komunikasi antarperorangan yang bersifat pribadi baik yang terjadi secara langsung (tanpa medium) maupun tidak langsung (melalui medium). Contohnya kegiatan percakapan tatap muka, percakapan melalui telepon, surat menyurat pribadi. Fokus pengamatannya adalah bentuk-bentuk dan sifat hubungan (relationship), percakapan (discourse), interaksi dan karakteristik komunikator.

Arni Muhammad (2009) mendefensikan "Komunikasi interpersonal adalah proses pertukaran informasi di antara seseorang dengan paling kurang seorang lainnya atau biasanya di antara dua orang yang dapat langsung diketahui balikannya. Dengan bertambahnya orang yang terlibat dalam komunikasi, menjadi bertambahlah persepsi orang dalam kejadian komunikasi sehingga bertambah komplekslah komunikasi tersebut.

Menurut Mulyana (2000) Komunikasi interpersonal adalah komunikasi antara orangorang secara tatap muka, yang memungkinkan setiap pesertanya menangkap reaksi orang lain secara langsung, baik secara verbal atau nonverbal. Komunikasi interpersonal ini adalah komunikasi yang hanya dua orang, seperti suami istri, dua sejawat, dua sahabat dekat, gurumurid dan sebagainya. Menurut Hardjana (2003) Komunikasi interpersonal adalah interaksi tatap muka antar dua atau beberapa orang, dimana pengirim dapat menyampaikan pesan secara langsung, dan penerima pesan dapat menerima dan menanggapi secara langsung pula.

Gitosudarmo dan Mulyono (2001) mengartikan bahwa komunikasi interpersonal merupakan komunikasi tatap muka (face to face) ini merupakan hal yang penting bagi seorang manager atau pemimpin. Keberhasilan dalam komunikasi ini merupakan faktor penentu bagi keberhasilan organisasi dalam mencapai tujuan.

Secara keseluruhan, komunikasi interpersonal dapat dilakukan dengan baik dan tidak langsung media komunikasi langsung seperti interaksi tatap muka, serta komputer-mediatedkomunikasi. Komunikasi dapat dikatakan sukses apabila, baik pengirim pesan dan penerima pesan akan menafsirkan dan memahami pesan-pesan yang dikirim dengan makna dan implikasi pada tingkat yang sama. Tujuan komunikasi adalah untuk memberikan keterangan tentang sesuatu kepada penerima, memengaruhi sikap penerima, memberikan dukungan psikologis kepada penerima, atau memengaruhi penerima.

\section{d. Kinerja karyawan}

Kinerja (job performance) adalah catatan hasil atau keluaran (outcome) yang dihasilkan dari suatu fungsi pekerjaan tertentu atau kegiatan tertentu dalam suatu periode waktu tertentu 
(Gomes, 2003). Menurut Mangkunegara (2006), kinerja adalah hasil kerja secara kualitas dan kuantitas yang dicapai oleh seseorang dalam melaksanakan tugasnya sesuai dengan tanggung jawab yang diberikan kepadanya secara efesien dan efektif penuh kesetiaan.

Menurut Hasibuan (2002) kinerja adalah merupakan suatu hasil kerja yang dicapai seseorang dalam melaksanakan tugas-tugasnya atas kecakapan, usaha dan kesempatan. Berdasarkan paparan diatas kinerja adalah suatu hasil yang dicapai seseorang dalam melaksanakan tugas-tugas yang didasarkan atas kecakapan, pengalaman dan kesungguhan serta waktu menurut standar dan kriteria yang telah ditetapkan sebelumnya.

Kinerja menurut Gomes (2003) kinerja karyawan sebagai ungkapan seperti output, efisiensi serta efektivitas sering dihubungkan dengan produktivitas. Kinerja menurut Simamora (2004) bahwa untuk mencapai agar organisasi berfungsi secara efektif dan sesuai dengan sasaran organisasi, maka organisasi harus memiliki kinerja karyawan yang baik yaitu dengan melaksanakan tugas-tugasnya dengan cara yang handal. Menurut Mangkunegara (2006) bahwa kinerja (prestasi kerja) adalah hasil kerja secara kualitas dan kuantitas yang dicapai oleh seorang karyawan dalam melaksanakan tugasnya sesuai dengan tanggung jawab yang diberikan kepadanya. Kinerja menurut Mathis dan Jackson (2006) adalah apa yang dilakukan atau tidak dilakukan oleh karyawan.

Menurut Simamora (2004), deskripsi dari kinerja menyangkut tiga komponen penting, yaitu tujuan yang akan memberikan arah dan mempengaruhi bagaimana seharusnya perilaku kerja yang diharapkan organisasi terhadap setiap personel. Kedua adalah ukuran, dibutuhkan untuk mengetahui apakah seorang personel telah mencapai kinerja yang diharapkan, untuk itu kuantitatif dan kualitatif standar kinerja untuk setiap tugas dan jabatan personal memegang peranan penting. Ketiga, penilaian kinerja reguler, yang dikaitkan dengan proses pencapaian tujuan kinerja setiap personel. Tindakan ini akan membuat personel untuk senantiasa berorientasi terhadap tujuan dan berperilaku kerja sesuai dan searah dengan tujuan yang hendak dicapai.

\section{e. Hubungan Antar Variabel}

Insentif, komitmen organisasi dan komunikasi interpersonal diduga memiliki pengaruh yang kuat terhadap kinerja karyawan dengan demikian jika insentif, komitmen organisasi dan komunikasi interpersonal ini dihubungkan terhadap kinerja karyawan maka akan diperoleh dampak yang lebih tinggi. Dimana jika insentif, komitmen organisasi dan komunikasi interpersonal baik maka akan meningkatkan kinerja karyawan yang lebih baik pula. Keterhubungan antara insentif, komitmen organisasi dan komunikasi interpersonal dengan kinerja karyawan diuraikan sebagai berikut:

Menurut Hasibuan (2002), mengemukakan bahwa Insentif adalah tambahan balas jasa yang diberikan kepada karyawan tertentu yang prestasinya di atas prestasi standar. Insentif ini merupakan alat yang dipergunakan pendukung prinsip adil dalam pemberian kompensasi. Selain itu menurut Mangkunegara (2006), mengemukakan bahwa Insentif adalah suatu bentuk motivasi yang dinyatakan dalam bentuk uang atas dasar kinerja yang tinggi dan juga merupakan rasa pengakuan dari pihak organisasi terhadap kinerja karyawan dan kontribusi terhadap organisasi. Penelitian yang dilakukan Mazura, Mujiono dan Rosmida, (2012) menemukan bahwa terdapat pengaruh Insentif terhadap kinerja karyawan.

Menurut Luthans (2006), komitmen diartikan secara umum sebagai sikap yang menunjukkan loyalitas karyawan dan merupakan proses berkelanjutan bagaimana seorang karyawan instansi mengekspresikan perhatian mereka kepada kesuksesan dan kebaikan organisasinya. Karyawan dengan komitmen tinggi akan memberikan dampak positif dalam bekerja, yaitu memberikan usaha terbaiknya untuk menyelesaikan tugas dengan cepat dan sesuai apa yang ditargetkan. Pendapat lain dikemukakan oleh Handoko (2008), komitmen karyawan adalah tingkatan dimana seorang pekerja mengidentifikasikan diri dengan organisasi 
Nuraeni Gani. Determinan Kinerja Karyawan Bank Sulselbar Syariah.

dan tujuan-tujuannya dan berkeinginan untuk memelihara keanggotaannya dalam organisasi. Komitmen karyawan didorong dengan kondisi lingkungan kerja yang adil untuk karyawan, semakin tinggi karyawan dihargai, semakin tinggi juga komitmen karyawan pada organisasi tersebut. Penelitian yang dilakukan Arizona, D Dika dkk (2013) menemukan bahwa variabel komitmen organisasional berpengaruh terhadap kinerja karyawan.

Menurut Kohler (dalam Devito (2011)) ada dua model komunikasi dalam rangka meningkatkan kinerja dan mencapai tujuan perkantoran. Pertama, komunikasi koordinatif, yaitu proses komunikasi yang berfungsi untuk menyatukan bagian-bagian (subsistem) perkantoran. Kedua, komunikasi interaktif, ialah proses pertukaran informasi yang berjalan secara berkesinambungan, pertukaran pendapat dan sikap yang dipakai sebagai dasar penyesuaian di antara sub-sub sistem dalam perkantoran, maupun antara perkantoran dengan mitra kerja. Penelitian yang dilakukan Beny Usman (2013)menemukan bahwa ada pengaruh yang signifikan antara komunikasi interpersonal terhadap kinerja karyawan.

Untuk mengetahui pengaruh insentif, komitmen organisasi dan komunikasi interpersonalterhadap kinerja karyawan, maka dibuatlah suatu kerangka pikir. insentif, komitmen organisasi dan komunikasi interpersonal adalah sebagai variabel bebas (variabel Independen), sedangkan kinerja karyawan adalah variabel terikat (variabel dependen), maka hubungan antara variabel-variabel bebas dan variabel terikat dalam penelitian ini digambarkan dalam kerangka pikir sebagai berikut,

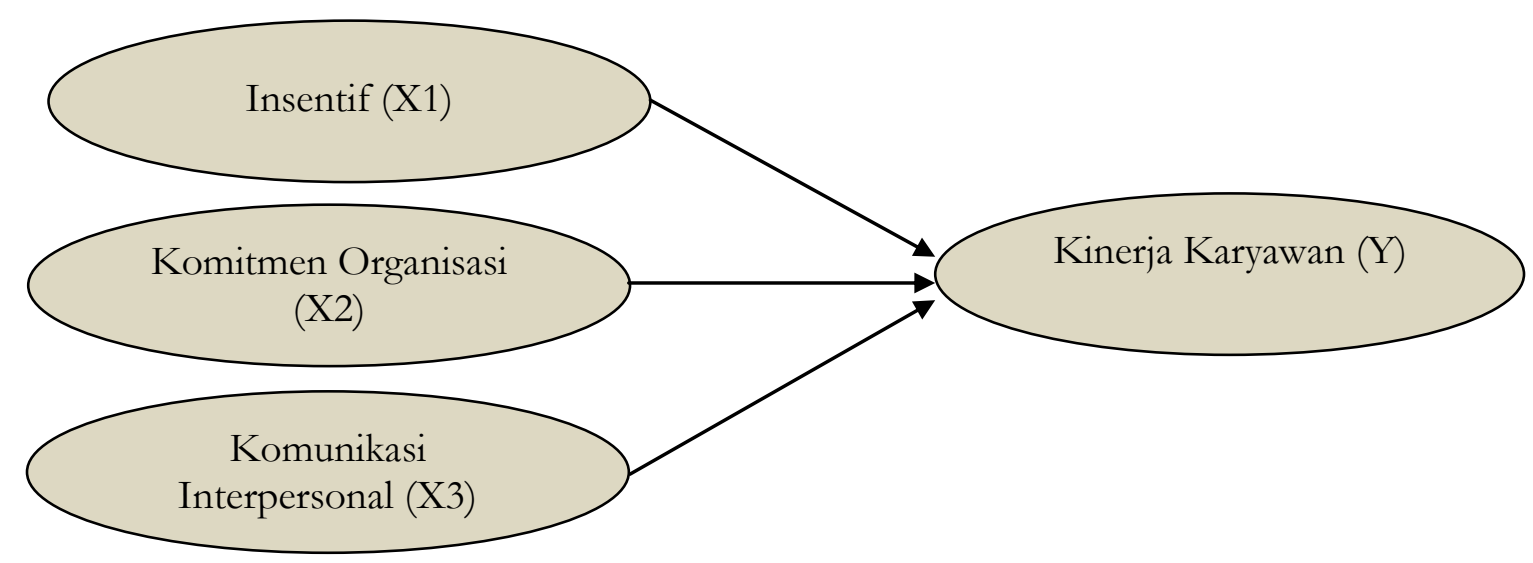

Gambar 1. Kerangka Pikir

\section{METODE PENELITIAN}

Penelitian ini dilaksanakan di Bank Sulselbar Syariah. Jenis data dalam penelitian ini adalah data kualitatif dan data kuantitatif. Sumber data yang digunakan dalam penelitian ini adalah sumber data primer dan data sekunder. Pengumpulan data dalam penelitian ini dilakukan dengan: (1) Observasi, (2) Wawancara, (3) kuesioner, dan (4) dokumentasi. Populasi dan sampel pada penelitian ini adalah sebagai berikut: (1) Subjek penelitian yang akan dijadikan populasi adalah seluruh karyawan/guru/karyawan di Bank Sulselbar Syariah dengan jumlah populasi penelitian sebanyak 47 orang. Menurut Sugiyono (2009) Sampel merupakan bagian dari populasi yang menjadi sumber data dalam penelitian, yang mana adalah merupakan bagian dari jumlah karakteristik yang dimiliki oleh populasi. Dalam penelitian dilakukan terhadap sampel yang mewakili populasinya. Dalam penelitian ini peneliti menggunakan teknik sampling jenuh karena jumlah populasi relatif kecil. "Sampel jenuh adalah teknik penentuan sampel bila semua anggota populasi digunakan sebagai sampel" (Sugiyono, 2009). Istilah lain dari sampling 
jenuh adalah sensus, dimana semua anggota populasi dijadikan sampel. Dimana sampel dalam penelitian ini adalah seluruh karyawan di Bank Sulselbar Syariah dengan jumlah sampel penelitian sebanyak 47 orang. Teknik analisis data yang digunakan dalam penelitian adalah analisis regresi linear berganda yang terdiri atas uji signifikansi simultan (uji $f$ ), dan uji parsial (uji $t$ ).

\section{HASIL DAN PEMBAHASAN}

\section{a. Analisis Regresi Linear Berganda}

Untuk melihat pengaruh insentif, komitmen organisasi dan komunikasi interpersonal terhadap kinerja karyawan, maka digunakan analisa regresi linear berganda. Berdasarkan hasil pengolahan data dengan bantuan program SPSS 19.0 dapat dilihat rangkuman hasil empiris penelitian sebagai berikut:

Tabel 1. Output Hasil Regresi Berganda

\begin{tabular}{|c|c|c|c|c|c|c|}
\hline & \multirow[t]{2}{*}{ Model } & \multicolumn{2}{|c|}{$\begin{array}{l}\text { Unstandardized } \\
\text { Coefficients }\end{array}$} & \multicolumn{3}{|l|}{$\begin{array}{l}\text { Standardized } \\
\text { Coefficients }\end{array}$} \\
\hline & & $\mathrm{B}$ & Std. Error & Beta & $\mathrm{t}$ & Sig. \\
\hline \multirow[t]{4}{*}{1} & (Constant) & .113 & 3.583 & & .031 & .975 \\
\hline & Insentif (x1) & .816 & .178 & .509 & 4.597 & .000 \\
\hline & Komitmen organisasi (x2) & .479 & .137 & .378 & 3.496 & .001 \\
\hline & Komunikasi interpersonal (x3) & .280 & .099 & .289 & 2.823 & .007 \\
\hline
\end{tabular}

Sumber : Data primer, diolah 2018

Persamaan regresi berganda yang diperoleh dari hasil analisis yaitu:

$\mathrm{Y}=0.113+0.816 \mathrm{X}_{1}+0.479 \mathrm{X}_{2}+0.280 \mathrm{X}_{3}$

Persamaan regresi tersebut mempunyai makna bahwa pengaruh insentif, komitmen organisasi dan komunikasi interpersonalterhadap kinerja karyawan adalah positif dimana saat insentif, komitmen organisasi dan komunikasi interpersonalmembaik akan meningkatkan kinerja karyawan. Ini mengindikasikan bahwa saat insentif, komitmen organisasi dan komunikasi interpersonalmeningkat maka akan diikuti peningkatan kinerja karyawan.

\section{Uji Parsial Dengan T-Test}

Berdasarkan tabel output hasil regresi bergandamenunjukkan bahwa:

a) Nilai $t$ hitung untuk variabel insentif terhadap kinerja karyawan diperoleh 4.597 dengan harga signifikansi 0.000 menunjukkan bahwa nilai t yang diperoleh tersebut signifikan karena harga signifikansi yang diperoleh kurang dari 0.05 . Karena nilai t hitung 4.597 lebih besar dari t tabel 1.677 maka hipotesis nol (H0) ditolak dan hipotesis dua $(\mathrm{H} 2)$ diterima, sehingga hal ini berarti bahwa variabel insentif $\left(\mathrm{X}_{1}\right)$ memiliki pengaruh yang signifikan terhadap kinerja karyawan (Y). Berdasarkan hasil diatas maka hipotesis 1 yang menyatakan insentif berpengaruh positif dan signifikan terhadap kinerja karyawan di Bank Sulselbar Syariah, terbukti dan diterima.

b) Nilai thitung untuk variabel komitmen organisasi terhadap kinerja karyawan diperoleh 3.496 dengan harga signifikansi 0.001 menunjukkan bahwa nilai t yang diperoleh tersebut signifikan karena harga signifikansi yang diperoleh kurang dari 0.05. Karena nilai t hitung 3.496 lebih besar dari t tabel 1.677 maka hipotesis nol (H0) ditolak dan hipotesis dua (H2) diterima, sehingga hal ini berarti bahwa variabel komitmen organisasi $\left(\mathrm{X}_{2}\right)$ memiliki pengaruh yang signifikan terhadap kinerja karyawan $(\mathrm{Y})$. Berdasarkan hasil diatas maka hipotesis 2 yang menyatakan komitmen organisasi 
Nuraeni Gani. Determinan Kinerja Karyawan Bank Sulselbar Syariah.

berpengaruh positif dan signifikan terhadap kinerja karyawan di Bank Sulselbar Syariah, terbukti dan diterima.

c) Nilai t hitung untuk variabel komunikasi interpersonal terhadap kinerja karyawan diperoleh 2.823 dengan harga signifikansi 0.007 menunjukkan bahwa nilai t yang diperoleh tersebut signifikan karena harga signifikansi yang diperoleh kurang dari 0.05. Karena nilai t hitung 2.823 lebih besar dari t tabel 1.677 maka hipotesis nol (H0) ditolak dan hipotesis dua (H2) diterima, sehingga hal ini berarti bahwa variabel komunikasi interpersonal $\left(\mathrm{X}_{3}\right)$ memiliki pengaruh yang signifikan terhadap kinerja karyawan (Y). Berdasarkan hasil diatas maka hipotesis 3 yang menyatakan komunikasi interpersonal berpengaruh positif dan signifikan terhadap kinerja karyawan di Bank Sulselbar Syariah, terbukti dan diterima.

\section{Uji Simultan Dengan F-Test (Anova ${ }^{\mathrm{b}}$ )}

Uji F untuk menentukan apakah secara serentak/bersama-sama variabel independen mampu menjelaskan variabel dependen dengan baik atau apakah variabel independen secara bersama-sama mempunyai pengaruh yang signifikan terhadap variabel dependen. Pada tabel Anova dapat dilihat pengaruh variabel independeninsentif, komitmen organisasi dan komunikasi interpersonal terhadap variabel dependen kinerja karyawandi Bank Sulselbar Syariahsecara simultan/bersama. Dimana setelah dilakukan penganalisaan dengan SPSS 19.0 maka didapat output sebagai berikut:

Tabel Output Uji F

\begin{tabular}{ccccccc}
\hline & Model & Sum of Squares & df & Mean Square & F & Sig. \\
\hline 1 & Regression & 106.274 & 3 & 35.425 & 19.354 & $.000^{\mathrm{a}}$ \\
& Residual & 78.705 & 43 & 1.830 & & \\
& Total & 184.979 & 46 & & & \\
\hline
\end{tabular}

Sumber : Data primer, diolah 2018

Berdasarkan Tabel Output Uji F menunjukkan bahwa hasil pengujian hipotesis dengan perhitungan uji $\mathrm{F}$ menggunakan program SPSS for Windows release 19.00 diperoleh $\mathrm{F}$ hitung $=19.354$ yang lebih besar dari $\mathrm{F}$ tabel sebesar 3.20 dan dengan harga signifikansi sebesar 0.000 . Karena harga signifikansi kurang dari 0.05 , menunjukkan bahwa nilai F hitung yang diperoleh tersebut signifikan. Dengan demikian menunjukkan bahwa secara bersama-sama terdapat pengaruh yang signifikan insentif, komitmen organisasi dan komunikasi interpersonal terhadap kinerja karyawan di Bank Sulselbar Syariah.

Berdasarkan hasil diatas maka hipotesis 4yang menyatakaninsentif, komitmen organisasi dan komunikasi interpersonal secara simultan berpengaruh positif dan sgnifikan terhadap kinerja karyawan di Bank Sulselbar Syariah, terbukti dan diterima.

\section{Koefisien Determinasi (R Square)}

Derajat pengaruh antar insentif, komitmen organisasi dan komunikasi interpersonal terhadap kinerja karyawan secara bersama-sama atau secara simultan dapat

Tabel Output Korelasi Simultan

\begin{tabular}{lcccc}
\hline Model & $\mathrm{R}$ & $\mathrm{R}$ Square & Adjusted R Square & $\begin{array}{c}\text { Std. Error of the } \\
\text { Estimate }\end{array}$ \\
\hline 1 & $.758^{\mathrm{a}}$ & .575 & .545 & 1.353 \\
\hline \multicolumn{4}{l}{ Sumber : Data primer, diolah 2018}
\end{tabular}


Berdasarkan hasil perhitungan diperoleh harga koefisien korelasi secara simultan sebesar 0.758 dengan nilai $\mathrm{R}$ square sebesar 0.575 . Ini mengindikasikan bahwa kuat pengaruh secara bersama-sama variabel insentif, komitmen organisasi dan komunikasi interpersonal terhadap kinerja karyawan masuk dalam kategori sedang. Besarnya pengaruh insentif, komitmen organisasi dan komunikasi interpersonal dapat diketahui dari harga koefisien determinasi simultan $\left(\mathrm{R}^{2}\right)$ yang menunjukkan secara bersama-sama insentif, komitmen organisasi dan komunikasi interpersonal memiliki pengaruh sebesar 57.5\% terhadapkinerja karyawan. Sedangkan selebihnya sebesar $42.5 \%$ adalah pengaruh faktor lain yang tidak dimasukkan ke dalam model ini.

\section{b. Pembahasan}

Berdasarkan hasil penelitian yang telah dikemukan pada bab sebelumnya, selanjutnya akan diibahas hasil penelitian sebagai berikut:

\section{Pengaruh Insentif terhadap Kinerja karyawan}

Penelitian ini menunjukkan bahwa adanya pengaruh positif dan signifikan secara parsial insentif terhadap kinerja karyawan. Hal ini terlihar dari hasil uji t anova didapatkan hasil insentif berpengaruh positif dan signifikan terhadap kinerja karyawan. Hasil penelitian ini sejalan dengan pernyataan Hasibuan (2002), mengemukakan bahwa Insentif adalah tambahan balas jasa yang diberikan kepada karyawan tertentu yang prestasinya di atas prestasi standar. Insentif ini merupakan alat yang dipergunakan pendukung prinsip adil dalam pemberian kompensasi. Selain itu menurut Mangkunegara (2006), mengemukakan bahwa Insentif adalah suatu bentuk motivasi yang dinyatakan dalam bentuk uang atas dasar kinerja yang tinggi dan juga merupakan rasa pengakuan dari pihak organisasi terhadap kinerja karyawan dan kontribusi terhadap organisasi. Insentif adalah penghargaan atas dasar prestasi kerja yang tinggi dan menjadi dorongan pada karyawan agar mau bekerja dengan baik dan agar lebih dapat mencapai tingkat kinerja yang lebih tinggi sehingga dapat membangkitkan gairah kerja. Hasil penelitian ini juga mendukung hasil penelitian sebelumnya dari Mazura, Mujiono dan Rosmida, (2012), bahwa insentif berpengaruh positif dan signifikan terhadap kinerja karyawan.

\section{Pengaruh Komitmen Organisasi terhadap Kinerja karyawan}

Penelitian ini menunjukkan bahwa adanya pengaruh positif dan signifikan secara parsial komitmen organisasi terhadap kinerja karyawan. Hal ini terlihar dari hasil uji t anova didapatkan hasil komitmen organisasi berpengaruh positif dan signifikan terhadap kinerja karyawan. Hasil penelitian ini sejalan dengan pernyataan Luthans (2006), bahwa komitmen diartikan secara umum sebagai sikap yang menunjukkan loyalitas karyawan dan merupakan proses berkelanjutan bagaimana seorang karyawan instansi mengekspresikan perhatian mereka kepada kesuksesan dan kebaikan organisasinya. Karyawan dengan komitmen tinggi akan memberikan dampak positif dalam bekerja, yaitu memberikan usaha terbaiknya untuk menyelesaikan tugas dengan cepat dan sesuai apa yang ditargetkan. Pendapat lain dikemukakan oleh Handoko (2008), komitmen karyawan adalah tingkatan dimana seorang pekerja mengidentifikasikan diri dengan organisasi dan tujuan-tujuannya dan berkeinginan untuk memelihara keanggotaannya dalam organisasi. Komitmen karyawan didorong dengan kondisi lingkungan kerja yang adil untuk karyawan, semakin tinggi karyawan dihargai, semakin tinggi juga komitmen karyawan pada organisasi tersebut.. Komitmen organisasi adalah totalitas perilaku karyawan dalam mematuhi ketentuan yang berlaku dalam suatu organisasi dan instansi tempat kerjanya. Hasil penelitian ini juga mendukung hasil penelitian sebelumnya dari Arizona, D Dika dkk (2013), bahwa komitmen organisasional berpengaruh positif dan signifikan terhadap kinerja karyawan. 
Nuraeni Gani. Determinan Kinerja Karyawan Bank Sulselbar Syariah.

\section{Pengaruh Komunikasi Interpersonal terhadap Kinerja karyawan}

Penelitian ini menunjukkan bahwa adanya pengaruh positif dan signifikan secara parsial komunikasi interpersonal terhadap kinerja karyawan. Hal ini terlihat dari hasil uji $\mathrm{t}$ anova didapatkan hasil komunikasi interpersonal berpengaruh positif dan signifikan terhadap kinerja karyawan. Hasil penelitian ini sejalan dengan pernyataan Kohler (dalam Devito (2011)) ada dua model komunikasi dalam rangka meningkatkan kinerja dan mencapai tujuan perkantoran. Pertama, komunikasi koordinatif, yaitu proses komunikasi yang berfungsi untuk menyatukan bagian-bagian (subsistem) perkantoran. Kedua, komunikasi interaktif, ialah proses pertukaran informasi yang berjalan secara berkesinambungan, pertukaran pendapat dan sikap yang dipakai sebagai dasar penyesuaian di antara sub-sub sistem dalam perkantoran, maupun antara perkantoran dengan mitra kerja. Komunikasi interpersonal adalah interaksi tatap muka antar dua atau beberapa orang, dimana pengirim dapat menyampaikan pesan secara langsung, dan penerima pesan dapat menerima dan menanggapi secara langsung pula. Hasil penelitian ini juga mendukung hasil penelitian sebelumnya dari Beny Usman (2013) bahwa terdapat pengaruh yang signifikan antara komunikasi interpersonal terhadap kinerja karyawan.

\section{Pengaruh Insentif, Komitmen organisasi dan Komunikasi Interpersonal terhadap Kinerja Karyawan}

Dari hasil uji $\mathrm{F}$ anova didapatkan hasil variabel insentif, komitmen organisasi dan komunikasi interpersonal berpengaruh positif dan signifikan secara simultan terhadap kinerja karyawan. hal ini terlihat dari nilai $\mathrm{F}$ hitung untuk variabel insentif, komitmen organisasi dan komunikasi interpersonal terhadap kinerja karyawan diperoleh 19.354 dengan taraf signifikansi 0.000. Berdasarkan hasil perhitungan diperoleh koefisien korelasi secara simultan sebesar 0.758 dengan nilai $\mathrm{R}$ square sebesar 0.575 , mengindikasikan bahwa pengaruh secara bersama-sama variabel insentif, komitmen organisasi dan komunikasi interpersonal terhadap kinerja karyawan masuk dalam kategori sedang. Besarnya pengaruh insentif, komitmen organisasi dan komunikasi interpersonal dapat diketahui dari niai koefisien determinasi $\left(R^{2}\right)$ yang menunjukkan secara bersama-sama insentif, komitmen organisasi dan komunikasi interpersonal memiliki pengaruh sebesar 57.5\% terhadapkinerja karyawan. Sedangkan selebihnya sebesar $42.5 \%$ adalah pengaruh faktor lain yang tidak dimasukkan ke dalam penelitian ini. Artinya bahwa, besarnya pengaruh insentif, komitmen organisasi dan komunikasi interpersonal dalam kategori sedang dalam mempengaruhi kinerja karyawan.

\section{PENUTUP}

\section{a. Kesimpulan}

Berdasarkan hasil penelitian dan pembahasan yang ada pada bab sebelumnya terkait dengan pengaruh insentif, komitmen organisasi dan komunikasi interpersonal terhadap kinerja karyawan, maka dapat disimpulkan sebagai berikut:

1. Insentif berpengaruh positif dan signifikan terhadap kinerja karyawan di Bank Sulselbar Syariah, yang berarti hipotesis yang menyatakan Insentifsatu berpengaruh positif dan signifikan terhadap kinerja karyawan di Bank Sulselbar Syariah, terbukti dan diterima.

2. Komitmen organisasi berpengaruh positif dan signifikan terhadap kinerja karyawan di Bank Sulselbar Syariah, yang berarti hipotesis dua yang menyatakan komitmen organisasi berpengaruh positif dan signifikan terhadap kinerja karyawan di Bank Sulselbar Syariah, terbukti dan diterima.

3. Komunikasi interpersonal berpengaruh positif dan signifikan terhadap kinerja karyawan di Bank Sulselbar Syariah, yang berarti hipotesis tiga yang menyatakan 
AL-MASHRAFIYAH: Jurnal Ekonomi, Keuangan dan Perbankan Syariah Volume 2, Nomor 1 April 2018

komunikasi interpersonal berpengaruh positif dan signifikan terhadap kinerja karyawan di Bank Sulselbar Syariah, terbukti dan diterima.

4. Insentif, komitmen organisasi dan komunikasi interpersonal secara simultan berpengaruh positif dan signifikan terhadap kinerja karyawan di Bank Sulselbar Syariah, yang berarti hipotesis empat yang menyatakan insentif, komitmen organisasi dan komunikasi interpersonal secara simultan berpengaruh positif dan signifikan terhadap kinerja karyawan di Bank Sulselbar Syariah berpengaruh positif dan signifikan terhadap kinerja karyawan di Bank Sulselbar Syariah, terbukti dan diterima.

\section{b. Saran}

Berdasarkan pembahasan yang telah dikemukan pada bab sebelumnya, secara terperinci dapat dikemukakan saran-saran, baik untuk pengembangan pengetahuan maupun untuk kepentingan praktis. Adapun saran-saran penelitian ini dijelaskan sebagai berikut:

1. Bank Sulselbar Syariah perlu meningkatkan faktor insentif, komitmen organisasi dan komunikasi interpersonal yang menjadi faktor-faktor penting yang berpengaruh secara langsung terhadap kinerja karyawan. Oleh karena itu, meningkatkan insentif, komitmen organisasi dan komunikasi interpersonal terhadap kinerja karyawan merupakan prioritas dari Bank Sulselbar Syariah.

2. Penelitian ini mengambil objek penelitian yaitu Bank Sulselbar Syariah. Dengan demikian kesimpulan yang diperoleh dalam penelitian ini tentunya belum memungkinkan untuk dijadikan kesimpulan yang berlaku umum jika diterapkan pada objek lain di luar objek penelitian ini.

3. Untuk penelitian yang akan datang disarankan untuk menambahkan variabel independen lainnya selain insentif, komitmen organisasi dan komunikasi interpersonal yang tentunya dapat mempengaruhi variabel dependen kinerja karyawan agar lebih melengkapi penelitian ini karena masih ada variabel-variabel independen lain di luar penelitian ini yang mungkin bisa mempengaruhi kinerja karyawan.

\section{DAFTAR PUSTAKA}

Anoraga, Panji dan Sri Suryati, 2005. Perilaku Keorganisasian, PT. Pustaka Jaya,. Jakarta

Arizona, D Dika dkk. 2013. Analisis Pengaruh Gaya Kepemimpinan, Motivasi Kerja Dan Komitmen Organisasional Terhadap Kinerja Karyawan (Studi Pada Dinas Kelautan Dan Perikanan Kabupaten Malang)

Arni Muhammad. 2009. Komunikasi Organisasi. Jakarta: Bumi Aksara

AW, Suranto. 2011. Komunikasi Interpersonal. Yogyakarta: Graha Ilmu

Beny Usman. 2013. Pengaruh Komunikasi Interpersonal Terhadap Kinerja karyawan Pada Fakultas Ekonomi Universitas PGRI Palembang. Jurnal Media Wahana Ekonomika, Vol. 10, No.1, April $2013: 1-18$

Ghozali, Imam. 2011. Aplikasi Analisis Multivariate dengan program SPSS, Badan Penerbit Universitas Diponegoro, Semarang.

Handoko, T. H. 2008. Manajemen Personalia dan Sumberdaya Manusia. Edisi Kedua. Yogyakarta: BPFE

Kuncoro, Mudrajad. 2009. Metode Riset Untuk Bisnis \& Ekonomi. Penerbit. Erlangga. Jakarta.

Marjianto. 2015. Pengarub Komunikasi Interpersonal Terbadap Kinerja karyawan Sekolah Tinggi Agama Buddha Negeri (STABN) Raden Wijaya Wonogiri Jawa Tengah. Widya Sandhi : ISSN. 19077351 - Volume 6. Nomor 1. Mei 2015

Martoyo, S. 2000, Manajemen Sumber Daya Manusia, BPFE, Yogjakarta 
Nuraeni Gani. Determinan Kinerja Karyawan Bank Sulselbar Syariah.

Mathis, Robert L. dan Jackson. John H. 2006. Human Resource Management (Manajemen Sumber Daya Manusia). Edisi 10. Jakarta: Salemba Empat

Mazura, Mujiono dan Rosmida, 2012, Pengarub Insentif Terbadap Kinerja Karyawan bank Sipil (Studi Kasus Pada Badan Kekaryawanan Daerah Kabupaten Bengkalis). Jurnal Ilmiah Mahasiswa Volume 1, No 1, Des, 2012 hlmn 19-27

Meyer, J.P., dan Allen, N. J. 2002. Commitment in the workplace theory research and application. California: Sage Publications

Mubarak, Mawardi. 2014. Pengarub Pemberian Insentif Terbadap Kinerja Karyawan Pada PT. Kima Makassar

Robbins, Stephen P. 2007. Perilaku Organisasi. Jakarta: Salemba Empat

Steers, Richard M dan Porter, Lyman W. 2011. Motivation and Work Behavior. New York: Mc. Graw-Hill

Sudarmanto. 2009. Kinerja Dan Pengembangan Kompetensi SDM. Cetakan Pertama. Pustaka Pelajar. Yogyakarta

Sugiyono, 2009. Metode Penelitian Kuantitatif, Kualitatif dan R®D. Bandung Alfabeta 